\title{
鉛高温はんだ代替・耐熱接合材料の特性
}

\author{
加藤 力弥 ${ }^{*}$, 山形 咲枝 ${ }^{*}$, 岡本 正英 ${ }^{* *}$, 池田 靖 ${ }^{* *}$
}

\section{Features of Heat-Resistant Jointing Material That Replaces High-Temperature Lead Solder}

Rikiya KATO*, Sakie YAMAGATA*, Masahide OKAMOTO** and Osamu IKEDA**

*千住金属工業株式会社田口研究所（干 120-8555 東京都足立区千住橋戸町 23）

**株式会社日立製作所生産技術研究所（干 244-0817 神奈川県横浜市戸塚区吉田町 292）

* Taguchi Laboratory, Senju Metal Industry Co., Ltd. (23 Senju Hashido-cho, Adachi-ku, Tokyo 120-8555)

**Production Engineering Research Laboratory, Hitachi, Ltd. (292 Yoshida-cho, Totsuka-ku, Yokohama-shi, Kanagawa 244-0817)

\begin{abstract}
At present, heat-resistance is given to a soldered joint by using a Pb-based single-alloy solder. In order to achieve $\mathrm{Pb}$-free soldering, a reliability test was conducted using a composite type solder paste to solder joints. From this test it was found that joints made using a composite-type solder paste were equal to or stronger than joints made using the $\mathrm{Pb}$-free single-alloy solder. It was also confirmed that the high-melting-point intermetallic compounds (IMC) were bonded continuously, forming a heat-resistant joint. The composite-type paste was prepared by mixing solder powder, $\mathrm{Cu}$ powder, and flux. This paper reports on the strength of the formed IMC of the joint after it is allowed to stand at a high temperature, the strength after a temperature cycle test, and the features observed in the structure of the soldered part before and after the test.
\end{abstract}

Key Words: Heat Proof Joint, Compound Material, SnAgCu Solder, Cu Powder

\section{1. 緒 言}

近年は地球環境の面からすべての人間社会において，環 境に配慮した活動が必然的に重要になっている。生産活動 における各種材料についても同じで，エコマテリアル材の 調達がどの企業でも必須であるため, 供給側においてもそ れに対応した材料の創製は, 日々求め続けられている。接 合材料としてのはんだ材においても開発が始まってからす でに 20 年が経過した。この時点から基本的な構成は変わっ ていない。それとともに基本的な問題も変わってはいない と言える。2006年に実施が始まった RoHS 規制でも除外項 目となった, 高温に固相温度をもつ高 $\mathrm{Pb}$ はんだ領域の合 金が，単一としては明確に存在していないことである。 Table 1 は, 単一合金であり, $270^{\circ} \mathrm{C}$ 以上の固相温度をもち, $320^{\circ} \mathrm{C}$ 位の液相温度を目標として, $\mathrm{Zn}$ 系, $\mathrm{Sb}$ 系を基本元素 として選択し，その他おおよそ考えられる添加元素を考慮 して行った試験結果を示した。測定はDSC（示差走査熱量 計）で行った。固相温度, 液相温度の最適化を図ったが, いずれにおいても意図した状況にはなり得なかった。元素 添加によって耐熱温度, 作業温度の最適化を図っても固相 温度は極端に低下してしまったり，液相温度はほとんど変 化せず，高温液相低温固相という溶融温度域の広域化をま
ねいたのみであった。

そのためにNEDOなどでも高温接合代替技術の開発に着 手したが，その前提となった調査段階 ${ }^{1)}$ からすでに代替は 非常に無理であるということから導電接着材料の方向がほ ぼ打ち出された。

Table 1. Composition and temperature of single alloy

\begin{tabular}{c|c|c|c|c|c|c|c|c|c|c|c|c|c}
\hline \multicolumn{1}{c|}{} & \multicolumn{7}{|c|}{ Alloy composition mass \% } & \multicolumn{3}{c}{ Temperature ${ }^{\circ} \mathrm{C}$} \\
\cline { 2 - 11 } No. & Zn & Al & Ag & Ge & Cu & In & Bi & Sb & Au & Sn & Solid & Peak & Liquid \\
\hline zn1 & 89 & 5 & & 6 & & & & & & & 355 & 358 & 381 \\
zn2 & 87 & 5 & & 6 & & & & 2 & & & 354 & 358 & 370 \\
zn3 & 87 & 5 & 2 & 6 & & & & & & & 355 & 361 & 379 \\
zn4 & 87 & 5 & & 6 & 2 & & & & & & 353 & 357 & 375 \\
zn5 & 88 & 5 & & 6 & & & & & & 1 & 193 & 354 & 367 \\
zn6 & 87 & 5 & & 6 & & & 2 & & & & 253 & 356 & 367 \\
zn7 & 83 & 6 & & 6 & & & 5 & & & & 254 & 356 & 364 \\
zn8 & 83 & 6 & & 6 & & 5 & & & & & 313 & 345 & 351 \\
Zn9 & 68 & 6 & & 6 & & 20 & & & & & 145 & 332 & 351 \\
zn10 & 58 & 6 & & 6 & & 30 & & & & & 143 & 321 & 352 \\
sb1 & & & 15 & & & & 10 & 50 & & 35 & 226 & 365 & 426 \\
sb2 & & & 15 & & & 10 & & 50 & & 35 & 338 & 369 & 398 \\
sb5 & & & 15 & & & 20 & & 45 & & 35 & 228 & 315 & 406 \\
sb6 & & & 15 & & & 10 & & 50 & 35 & 35 & 303 & 307 & 419 \\
au1 & & & 4 & & & & & & 42 & 54 & 235 & 240 & 308 \\
au2 & & & 10 & & & & & & 40 & 50 & 277 & 294 & 323 \\
\hline
\end{tabular}


Table 2. Composition of compound alloy

\begin{tabular}{c|c|c}
\hline $\begin{array}{c}\text { Mother material } \\
\text { group }\end{array}$ & $\begin{array}{c}\text { Mixed material } \\
\text { group }\end{array}$ & $\begin{array}{c}\text { Reactoin product } \\
\text { IMC group }\end{array}$ \\
\hline $\mathrm{Bi}-\mathrm{Ag}$ & $\mathrm{Ag}$ & $\mathrm{Ag}_{3} \mathrm{Sn}$ \\
$\mathrm{Bi}-\mathrm{Cu}$ & $\mathrm{Cu}$ & $\mathrm{Cu}_{3} \mathrm{Sn}$ \\
$\mathrm{Bi}-\mathrm{Zn}$ & $\mathrm{Co}$ & $\mathrm{Cu}_{6} \mathrm{Sn}_{5}$ \\
$\mathrm{Sn}-\mathrm{Ag}$ & $\mathrm{Ni}$ & $\mathrm{CoSn}_{2}$ \\
$\mathrm{Sn}-\mathrm{Bi}$ & $\mathrm{Cu}-\mathrm{Ni}$ & $\mathrm{NiBi}_{3}$ \\
$\mathrm{Sn}-\mathrm{Co}$ & $\mathrm{Cu}-\mathrm{Sn}$ & $\mathrm{Cu}_{2} \mathrm{Sb}_{3}$ \\
$\mathrm{Sn}-\mathrm{Cu}$ & $\mathrm{Ag}-\mathrm{Sn}$ & $\mathrm{Ag}_{3} \mathrm{In}$ \\
$\mathrm{Sn}-\mathrm{Zn}$ & $\mathrm{Cu}-\mathrm{Zn}$ & $\mathrm{CoSb}_{3}$ \\
$\mathrm{Sn}-\mathrm{Sb}$ & $\mathrm{Co}-\mathrm{Sb}$ & $\mathrm{NiSb}_{3}$ \\
$\mathrm{Sn}-\mathrm{Ag}-\mathrm{Cu}$ & $\mathrm{Sb}-\mathrm{Sn}$ & $\mathrm{SnSb}_{\mathrm{Sn}}$ \\
$\mathrm{Sn}-\mathrm{In}-\mathrm{Ag}$ & $\mathrm{Zn}-\mathrm{Ag}$ & $\mathrm{Cu}_{5} \mathrm{Zn}_{7}$ \\
\hline
\end{tabular}

これらの状況から技術としては古い，2種以上の金属の 組み合わせからなる複合材料についてその特性を検討した。 現在の高温はんだは, 部品内部の接合が数次の加熱によっ ても動かないこと，樹脂封止などは内部のはんだがこれを 壊さないこと, ソルダリング特性が良いこと, 信頼性寿命 に優れていること，などが要求される部分に応用されてい る。以上のような背景から，はんだ合金粉末，高融点合金 粉末，フラックスの混合から成り立つ複合材料について検 討を重ねた。

はんだ付けの分野に使用可能な複合材は Table 2 のよう なものがある。母体金属ははんだ付けおよび分散金属との 反応に使用されるため，低めの融点がよく濡れ性に優れる ほどよい。分散合金は母体と反応させて反応物を形成させ 被はんだ付け物同士を連続結合，または全体を反応物にし て高温耐熱性をもたなければならない。このため反応物の 融点は少なくとも $260^{\circ} \mathrm{C}$ 以上は必要である。母体金属また は分散金属はそれぞれ 2 種以上の混合でもよい結果を生じ る。例えば $\mathrm{SnAg}-\mathrm{Cu}-\mathrm{SnCu}$ 組み合わせなどである。

試験の結果，はんだ付け性に優れている母体金属は $\mathrm{Sn}-\mathrm{Ag}-\mathrm{Cu}$ 系で, $\mathrm{S} n-\mathrm{Bi}$ 系は低温接合に有利であり, Bi90 mass \% の合金は脆性が強いため信頼性に欠ける。分散 合金は Ni，Coなどははんだ付け時の反応速度が遅く均一な 反応物連続結合は難しかった。 $\mathrm{Ag}$ は反応は速く，接合部 をすべて反応物にした方が有利だが，そのためには 60 mass \% 以上にする必要がありコスト的に難題である。こ れらに較べて $\mathrm{Cu}$ 合金は連続結合型およびすべて反応物型 の両者に応用可能である。

以上の試験結果をもとに，本報告は $\mathrm{SnAgCu}$ を母体とし， 分散合金に $\mathrm{Cu}$ を用いて IMC の連続型結合について試験し た結果を述べる。

\section{2. 実験方法}

\section{1 実験材料}

試験材料はフラックスと，はんだ粉末と $\mathrm{Cu}$ 粉末を混合
した solder pasteを作成して用いた。粉末は $\mathrm{Sn} 3 \mathrm{Ag} 0.5 \mathrm{Cu}$ と $\mathrm{Sn}_{1} \mathrm{Ag}_{0.5} \mathrm{Cu}$ 合金を粒度 $15 \sim 25 \mu \mathrm{m}$ 範囲で球状粉を標準とし て用いたが必要に応じて他の粒度も用いた。Cu粉末は平均 $7.5 \mu \mathrm{m}$ 粒度, BET 比表面積 $1,600 \mathrm{~cm}^{2} / \mathrm{g}$, 酸素濃度 $0.08 \%$ の アトマイズ粉末を用いた。フラックスタイプは低ハロゲン のロジンタイプでフラックス量 $10 \mathrm{mass} \%$ ，金属 $90 \mathrm{mass} \%$ ではんだ粉末 70 mass \%，Cu粉末 30 mass \% を混合して標準 paste とした。混合率は試験の必要に応じて他の場合もあ る。

\section{2 試験片の作成}

上記の pasteを用いてセラミック基板上に $5 \mathrm{~mm}$ 角， $150 \mu \mathrm{m}$ 厚に印刷し，リフローした物を採り洗浄して化合物 生成量の試験片とした。ガラエポ基板(FR-4) Cu padに paste を厚さ $150 \mu \mathrm{m}$ で印刷し，キャパシタ 3216 を搭載し reflow 温度 $250^{\circ} \mathrm{C}$ ではんだ付けした基板を恒温放置試験, 温度サ イクル試験，組織観察などに用いた。リフローは SMIC STR-2010 $\mathrm{N}_{2}$ M-IIItype を用い， $\mathrm{N}_{2}$ は 40-50-40 L/minの総量 $130 \mathrm{~L} / \mathrm{min}$ で酸素濃度 $100 \mathrm{ppm}$ 以下で行った。

\section{3 金属間化合物の生成量測定}

試験片をDSCで測定し $400^{\circ} \mathrm{C}$ 付近に生じる熱量変化の大 きさと，加熱条件を比較することによって，はんだと分散 合金の反応による金属間化合物の生成量を知り，両者の最 適な混合比率や最適な加熱条件を調査する。 $\mathrm{Cu}$ の混合率

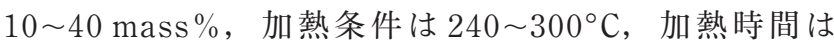
30 120 sec の範囲である。熱量測定はSII exster 6000 DSC 6200 を用いた。

\section{4 恒温放置試験}

試験基板を Yamato 製 DH410type $150^{\circ} \mathrm{C}$ 恒温槽内に置き 200，400，600，1000 時間まで放置試験を行った。試験を 終えた基板はシェア強度測定，組織観察を行った。シェア 強度はREHSCA 製 STR 1000 typeを用いて計測しシェアス ピード $20 \mathrm{~mm} / \mathrm{min}$ で行った。

\section{5 温度サイクル試験 (TCT)}

試験基板をEspec TSA101L ・ A type 温度サイクル槽内で 200，400，600， 1000 cycleまで行った。条件は $-55^{\circ} \mathrm{C}+$ $155^{\circ} \mathrm{C}$, 各 $30 \mathrm{~min}$, 途中 $25^{\circ} \mathrm{C}$ で $5 \min$ の放置がある。試験後 基板を取り出しシェア強度，組織観察を行った。

\section{6 組織観察}

恒温放置，温度サイクル試験を終了した基板の一部を切 り出し, エポキシ樹脂に埋め込み, 耐水研磨紙, バフ研磨 を施し試料とした。この後さらにイオンエッチングを行い, バフ研磨面の影響を除去するとともに組織境界の明確化を 行った。エッチングはSII 製FIB 3050SEを用いて行ったが, ビームはスキャンスピードやプローブ電流によって，大き く完了時間が変化しまた仕上がり表面状態も変わるが，今 回はエッチングが 1 2 時間で終了する条件とした。組織観 察はFE SEM (JEOL, JSM7000F)を用い元素定量も行った。 その他塩酸，硝酸混液でのエッチングも行った。 


\section{3. 結果および考察}

\section{1 金属間化合物 (IMC) の生成量}

セラミック基板上において，はんだとCu粉末間のみに起 こる反応量を検討するためリフローで生成した金属間化合 物 (IMC)の量を, 試料中で吸収された全熱量（母体のはん だが溶解する熱量 +IMCが溶解する熱量）と IMCが溶解す る熱量との比で行った。Fig. 1 はDSCで計測した試料の熱 量一温度図例である。最初にはんだの吸熱, 後半にIMCの 吸熱が見られる。Fig. 2 は Cu混合率, 温度 $240 \sim 300^{\circ} \mathrm{C}$, 時 間 30 120秒のリフロー条件下の試料をDSC 測定した結果 である。この範囲での加熱条件では熱量差は小さく, 母体 はんだが溶解すれば高速で反応が起こることを示す。また $\mathrm{Cu}$ 混合率に対しては直線的変化をする。このことは $\mathrm{Cu}$ 粉 末個々の表面とはんだとの反応は，ほぼ $100 \%$ いつでも行 われていることを示す。

\section{2 恒温放置による接合強度評価}

キャパシタ 3216 を実装した基板の $150^{\circ} \mathrm{C}$ 恒温放置による Sn3Ag0.5Cuはんだ付け接合強度変化を Fig. 3 に示した。 Fig. 4 にははんだを $\mathrm{Sn} 1 \mathrm{Ag} 0.5 \mathrm{Cu}$ に変えて同様の試験をした 結果を示す。これは低 $\mathrm{Ag}$ タイプにしてコストを考慮した ときの変化を見るためである。

$\mathrm{Sn}_{3} \mathrm{Ag}_{0.5} \mathrm{Cu}$ において, Cu30 mass\% の混合は初期強度は Cuなしに比較して，およそ10\%の低下が見られる。しか し1,000 時間後には $10 \%$ 程度の強度上昇が見られる。した がって $n=30$ 個の試験結果でのばらつきなどを考えると Cu30 mass\% の混合の有無は 1,000 時間後の信頼性強度は変 わらないと言える。また $1 \mathrm{Ag} の$ 場合は初期だけを見ると

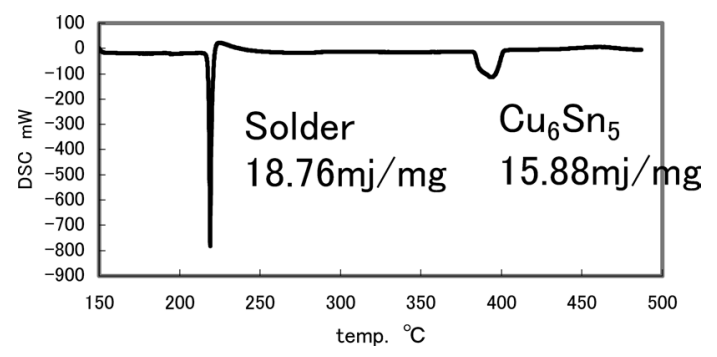

Fig. 1 Dissolution calorie of solder and IMC

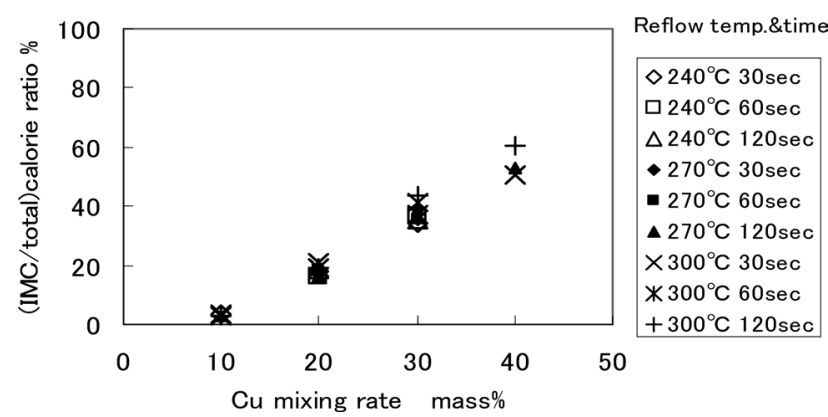

Fig. 2 Relation between IMC calorie ratio and Cu mixing rate and reflow temperature time
$3 \mathrm{Ag}$ よりも $10 \%$ 程度強度の低下があるがその後変化がな く, Cu $30 \%$ 混合も $3 \mathrm{Ag}$ と同様に上昇し $\mathrm{Cu}$ なしと同じにな る。これらの結果から $\mathrm{Sn}_{3} \mathrm{Ag}_{0.5} \mathrm{Cu}, \mathrm{Sn}_{1} \mathrm{Ag}_{0.5} \mathrm{Cu}, 150^{\circ} \mathrm{C}$ 放置, 1,000 時間後, キャパシタ 3216 という範囲では接合強度の 差はないといえる。また今回の試験結果では恒温放置によ る接合部へのストレスはないと言える。

\section{3 温度サイクル試験結果}

$\mathrm{Sn}_{3} \mathrm{Ag}_{0.5} \mathrm{Cu}$ はんだ，キャパシタ $3216 て ゙$ 基板作成し，温度 サイクル試験した結果をFig. 5 に示した。また Fig. 6 には低 $\mathrm{Ag}$ 化した $\mathrm{Sn}_{1} \mathrm{Ag}_{0.5} \mathrm{Cu}$ はんだの結果も示す。サイクルによる 接続強度の挙動として基本的には初期より低下する。しか し Cu粉末の混合はいずれのはんだも 500 サイクル以上でも 変化がほぼなくなり，強度の維持が起こっている。この原 因を見極めるのは現在できていないが，恒温放置での強度 上昇と関連して考えると, 接続強度に影響を与える部位,

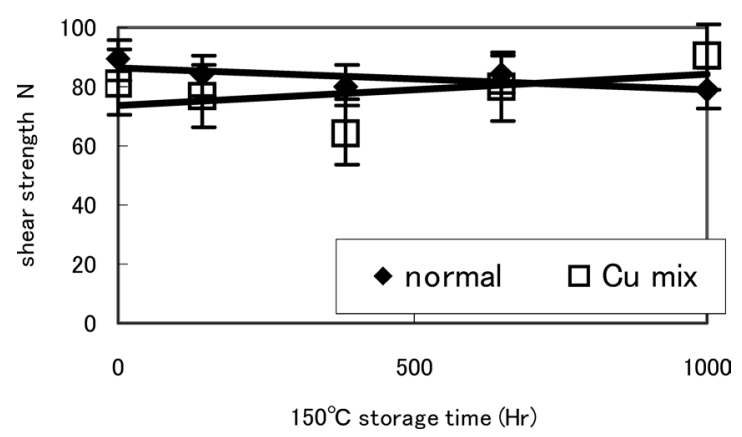

Fig. 3 Joint strength after constant temperature storage of $\mathrm{Sn}_{3} \mathrm{Ag}_{0.5} \mathrm{Cu}$ soldering capacitor

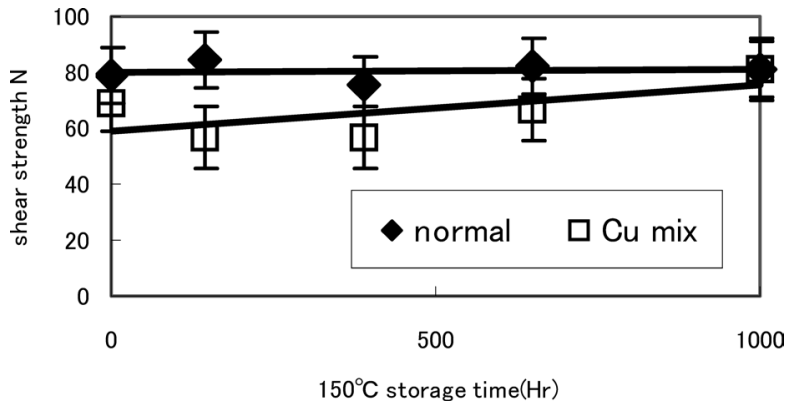

Fig. 4 Joint strength after constant temperature storage of $\mathrm{Sn}_{1} \mathrm{Ag}_{0.5} \mathrm{Cu}$ soldering capacitor

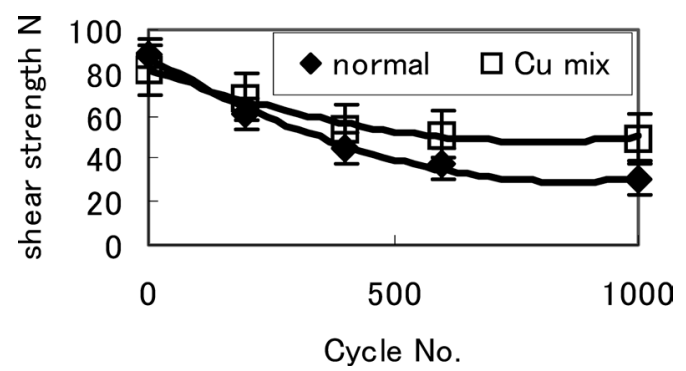

Fig. 5 Joint strength after TCT $\left(-55+155^{\circ} \mathrm{C}\right)$ of $\mathrm{Sn}_{3} \mathrm{Ag}_{0.5} \mathrm{Cu}$ (normal and Cu mix) soldering capacitor 


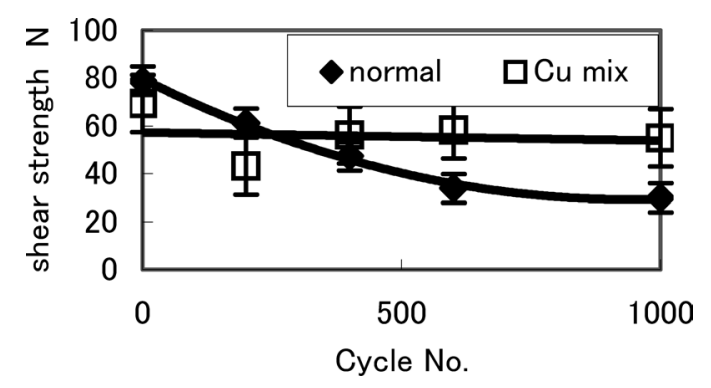

Fig. 6 Joint strength after TCT $\left(-55+155^{\circ} \mathrm{C}\right)$ of $\mathrm{Sn}_{1} \mathrm{Ag}_{0.5} \mathrm{Cu}$ (normal and $\mathrm{Cu} \mathrm{mix}$ ) soldering capacitor

接続界面において強固な IMC の成長，あるいは熱応力破壊 のクラック成長を抑制する，はんだ内の IMC 成長によるの ではないかと考察される。

温度サイクル後の接続強度は観察によると, 金属的な接 合をとっていると考えられる場合は $30 \mathrm{~N}$ 以上である。片側 接続はほぼ破壊していると考えられる時の接続強度は $20 \mathrm{~N}$ 程度であった。したがって, この強度の時は電気的導通が あるかは不明だが，基本的には部品両端にある接続のうち 片側電極部接続強度を示しているとも言える。これらのこ とからも今回の試験では, はんだ合金 $\mathrm{Sn}_{3} \mathrm{Ag}_{0.5} \mathrm{Cu}$, $\mathrm{Sn}_{1} \mathrm{Ag}_{0.5} \mathrm{Cu}$ 温度サイクル 1,000 回の範囲内では相違はなく $\mathrm{Cu}$ 粉末混合の有無によって大きな違いが生じている。

\section{4 組織観察結果}

組織の観察は複合材料の基本的な構造を知るうえで，ま た接続強度あるいは信頼性寿命を考えるうえで最も重要な 手がかりになる。このため研磨による組織のみならず, 酸 によるエッチング，イオンスパッタエッチングなどを行い, できるだけ正確な組織検証を行った。

Fig. 7 は $\mathrm{Cu}$ に $\mathrm{Sn}_{3} \mathrm{Ag}_{0.5} \mathrm{Cu}$ はんだの接合部を酸エッチング したときの確認される各部の状況を示す。a は Cu pad表面 に生成した $\mathrm{SnCu}$ 化合物, b 状化合物, $\mathrm{c}$ ははんだ中の成長した $\mathrm{SnCu}$ 化合物, $\mathrm{d}$ ははん だ中で $\mathrm{Sn}$ 初晶の間を埋める $\mathrm{SnAgCu}$ 共晶中の $\mathrm{SnAg}$ 化合物 を表す。共晶を形成している SnAg 化合物は微細な糸状が 縦横に組み合わさった構造で, Ag の量によってこの密度 が変化することでバルクの強度に影響すると考えられる。

Fig. 8 は，はんだ付けはんだ部の断面組織である。いず れもイオンスパッタエッチングによるがその深さが異なる。 $\mathrm{a}$ は平坦部が初晶の $\mathrm{Sn}$ で, 黒点模様部が共晶部で黒点が $\mathrm{SnAg}$ 化合物である。b は恒温放置後のはんだ部で粒状に見 えるのが $\mathrm{SnAg}$ 化合物である。c，d は $\mathrm{a} ， \mathrm{~b}$ そぞれをエッ チングを深くし拡大した $\mathrm{Ag}_{3} \mathrm{Sn}$ 部である。

これらによってはんだに熱処理を施すと, 初期 $\mathrm{Ag}_{3} \mathrm{Sn}$ の 微細単独組織は近辺にある $\mathrm{Ag}_{3} \mathrm{Sn}$ IMC が集合体に変化して いることがわかった。また定量すると上記したすべての $\mathrm{Ag}_{3} \mathrm{Sn}$ は $\mathrm{Ag} 70 \mathrm{mass} \%, \mathrm{SnCu}$ は $40 \mathrm{Cu}$ mass \% 以上となって おり，構造は $\mathrm{Ag}_{3} \mathrm{Sn}_{2} \mathrm{Cu}_{6} \mathrm{Sn}_{5}$ と考えられる。

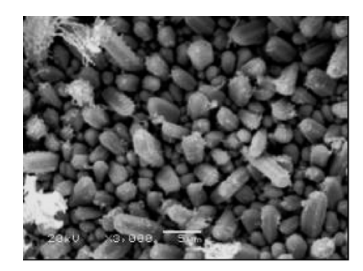

a

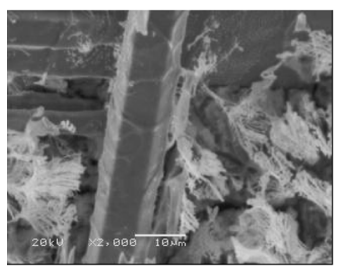

c $\overline{10 \mu \mathrm{m}}$

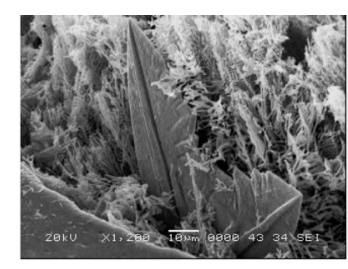

b $\overline{20 \mu} \mathbf{m}$

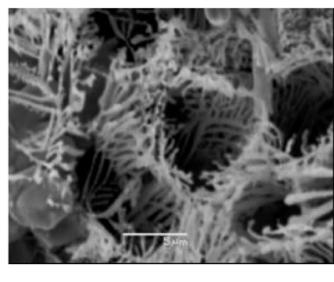

d

$\overline{10 \mu \mathrm{m}}$
Fig. 7 Micro structure with acid etching of $\mathrm{Sn}_{3} \mathrm{Ag}_{0.5} \mathrm{Cu}$ Soldered on Cu pad. a. $\mathrm{Cu}_{6} \mathrm{Sn}_{5}$ on pad b. $\mathrm{Ag}_{3} \mathrm{Sn}$ on pad. c. $\mathrm{Cu}_{6} \mathrm{Sn}_{5}$ in solder d. $\mathrm{Ag}_{3} \mathrm{Sn}$ in solder

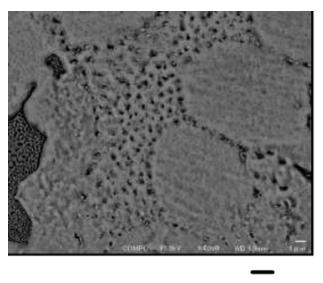

a

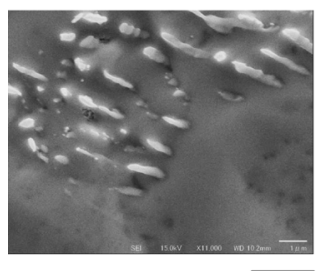

c

$2 \mu \mathrm{m}$

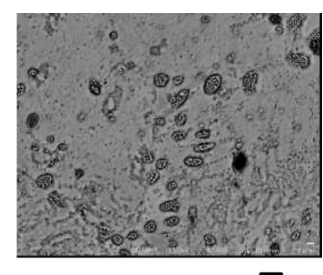

b

$2 \mu \mathrm{m}$

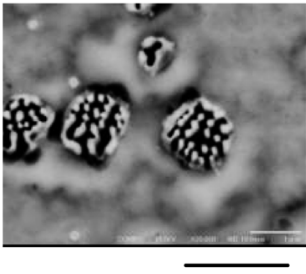

d

$2 \mu \mathrm{m}$
Fig. 8 Micro structure with ion etching of $\mathrm{Sn}_{3} \mathrm{Ag}_{0.5} \mathrm{Cu}$ in solder of soldering a. initial b. after storage $\mathbf{c}$. ion etching of initial $d$. ion etching of storage

Fig. 9 は Cu pad はんだ付け部の界面，およびはんだ粉末 とはんだ界面の断面組織を示した。aははんだ付け初期 pad 界面組織で $\mathrm{Cu}_{3} \mathrm{Sn}$ は $200 \mathrm{~nm}$ 位の非常に薄い層しかなく, $\mathrm{Cu}$ との界面にはボイドなどはない。反応物は $\mathrm{Cu}_{6} \mathrm{Sn}_{5}$ が bump の連続体のようになっている。この成長の度合いは個々に 大きなばらつきがある。bは熱経時後の pad界面組織で特 徵は $\mathrm{Cu}_{3} \mathrm{Sn}$ の成長とこの界面層でのボイドが多く見られる ことである。c $\mathrm{d}$ は熱経時後の反応で pad 界面と同じく $\mathrm{Cu}_{3} \mathrm{Sn}$ の成長とそ の層でのボイドの多発が見られる。このボイドは初期には 全く見られず，拡散速度差によるカーケンダルボイドと見 られる。

はんだ付け時には $\mathrm{Cu} \operatorname{pad}$ 界面の反応は $\mathrm{Cu}$ 粉末の有無に かかわらずほとんど相違はないが，経時によってその挙動 

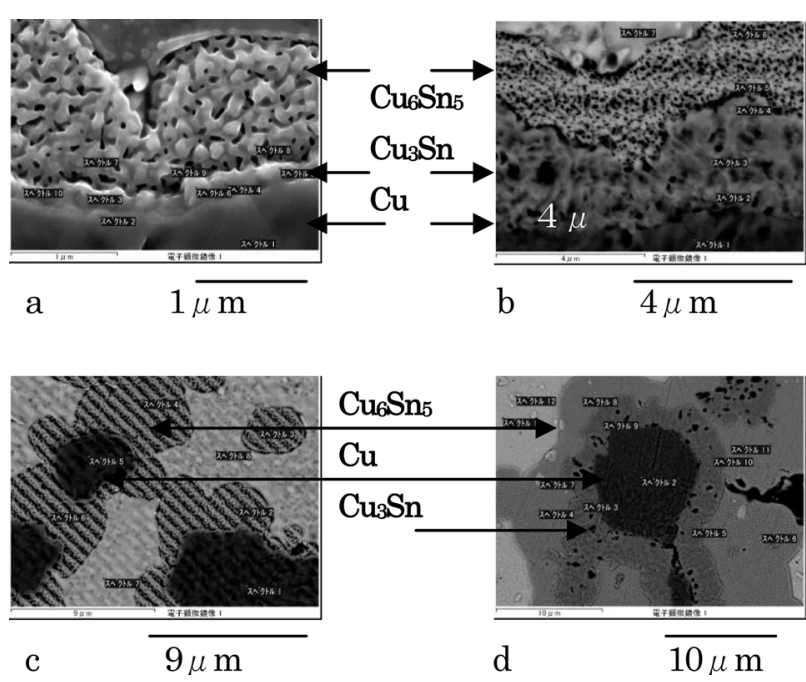

Fig. 9 Micro structure at the reaction of after storage with $\mathrm{Cu}$ in each part $\mathrm{a}$. initial $\mathrm{Cu}$ pad-solder $\mathrm{b}$. after storage $\mathrm{Cu}$ pad-solder $\mathrm{c}$ initial compound alloy d. after storage Cu powder-solder

が変化している。Fig. 10, Fig. 11にその変化を示した。殏 中の各ポイントは1条件での測定 10 20回の值を示してい る。反応量は $\mathrm{Cu}_{3} \mathrm{Sn}$ と $\mathrm{Cu}_{6} \mathrm{Sn}_{5}$ 別に測定しているので合計す ると総反応量になる。Fig. 10.1 に示したように $\mathrm{Sn}_{3} \mathrm{Ag}_{0.5} \mathrm{Cu}$ 単一はんだでは $150^{\circ} \mathrm{C} て ゙ ~ 1,000$ 時間の熱処理後でも $\mathrm{Cu}_{3} \mathrm{Sn}$ の 成長は少なく $1 \mu \mathrm{m}$ ほどである。Fig. 10.2 に示した $\mathrm{Cu}_{6} \mathrm{Sn}_{5}$ は 増のようではあるが実際増加しているかどうかは不明であ る。これは計測方法が断面観察から行っていること, その ためその場の IMCのトップ位置ではないこと, Fig. 7a やFig. 9aに見られるように平坦でないことなど，そのつど計測さ れる状態が異なるので, ばらつきが非常に大きい。これに 対して $\mathrm{Cu}_{3} \mathrm{Sn}$ は固相拡散であるため均一に成長しており, ばらつきも小さい。このように考えると固相状態で padか らの $\mathrm{Cu}$ の拡散は $\mathrm{Cu}_{3} \mathrm{Sn}$ の成長に影響を与えていると考え る。次の $\mathrm{Cu}$ 粉末混合の場合はこの傾向がさらに大きい。

Fig. 11.1のように複合タイプは, 1,000 時間後の $\mathrm{Cu}_{3} \mathrm{Sn}$ の 成長が単一合金に比較して 3 倍ほど大きい。その理由は pad からの $\mathrm{Cu}$ 拡散が $\mathrm{Cu}_{3} \mathrm{Sn}$ 成長消費のみに使われたか, そのた めには近接している $\mathrm{Cu}$ 粉末生成化合物が，接合界面に移 行し $\mathrm{Cu}_{6} \mathrm{Sn}_{5}$ の維持, $\mathrm{Cu}_{3} \mathrm{Sn}$ の成長に関与したと考えられる が明確ではない。またサイクル試験による化合物成長挙動 は恒温放置に準じている。同じく $\mathrm{Sn}_{1} \mathrm{Ag}_{0.5} \mathrm{Cu}$ 合金の界面挙 動も同様である。

接合材料が $\mathrm{Cu}$ 以外の時の界面挙動の確認のため, Ni に 対する接合状態を Fig. 12 に示した。はんだ中に Cuが少な いときは界面は $\mathrm{Ni}_{3} \mathrm{Sn}_{4}, \mathrm{Cu}$ が多くなると $\mathrm{Cu}_{6} \mathrm{Sn}_{5}$ が主体とな る。また $\mathrm{Cu} へ の$ 接合と異なり $\mathrm{Ni}$ 接合は界面 $\mathrm{Cu}$ 供給が行わ れず $\mathrm{Cu}_{6} \mathrm{Sn}_{5}$ のままであり, したがって界面ボイドの発生は 起こらない。

Fig. 13 および 14 は，はんだ合金が $3 \mathrm{Ag}$ と $1 \mathrm{Ag}$ の違いによ

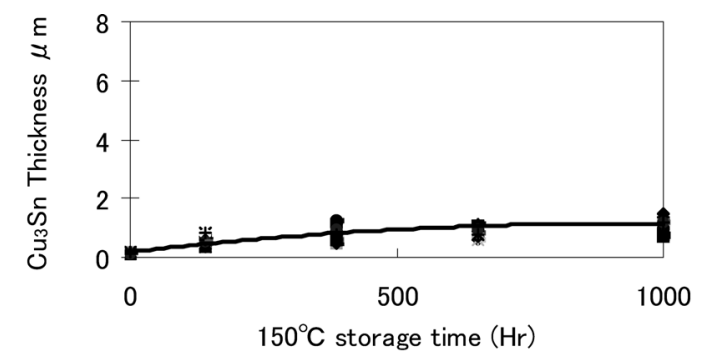

$10.1 \mathrm{Cu}_{3} \mathrm{Sn}$ Layer

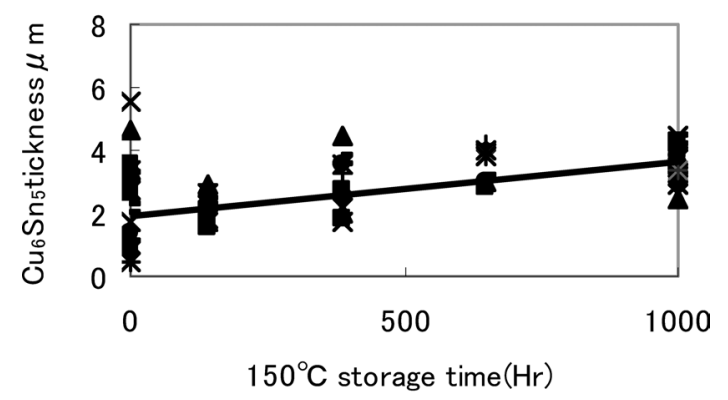

$10.2 \mathrm{Cu}_{6} \mathrm{Sn}_{5}$ Layer

Fig. 10 Growth of IMC layer by storage time of $\mathrm{Sn}_{3} \mathrm{Ag}_{0.5} \mathrm{Cu}$ single alloy

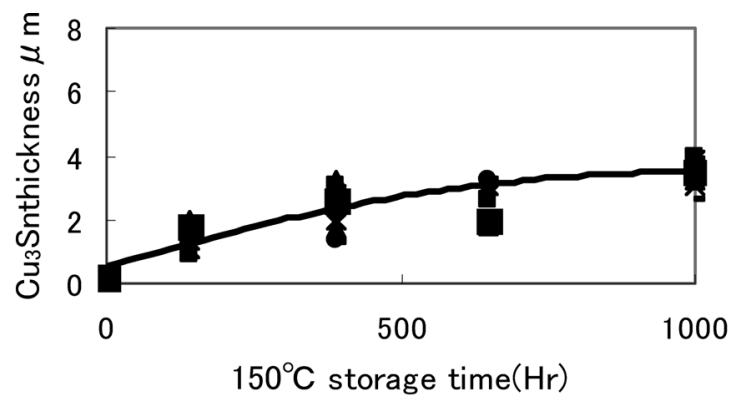

$11.1 \mathrm{Cu}_{3} \mathrm{Sn}$ Layer

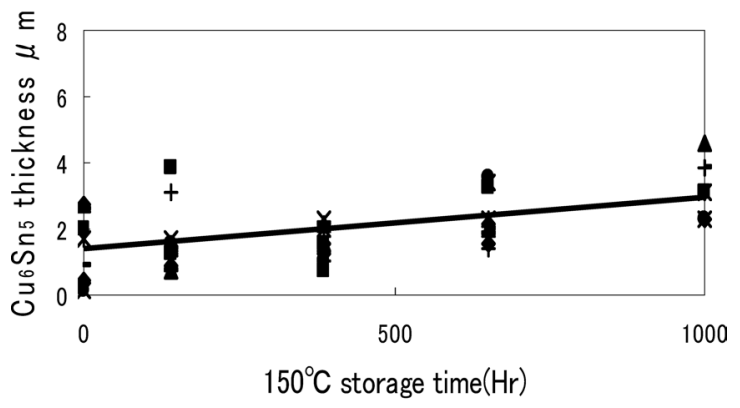

$11.2 \mathrm{Cu}_{6} \mathrm{Sn}_{5}$ layer

Fig. 11 Growth of IMC layer by storage of compound alloy $\left(\mathrm{Sn}_{3} \mathrm{Ag}_{0.5} \mathrm{Cu}\right.$ solder $+\mathrm{Cu}$ powder)

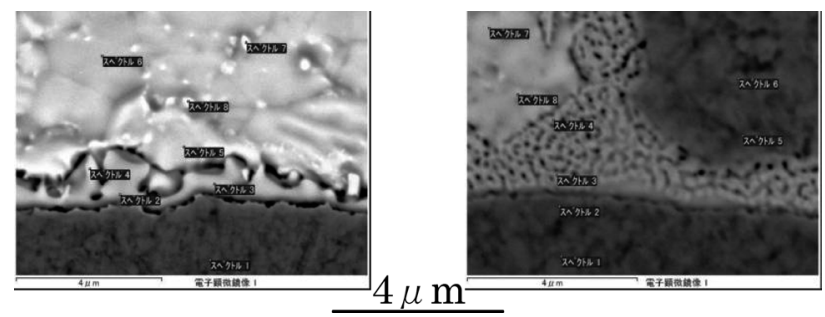

Fig. 12 Micro structure soldering with Ni pad left. Single alloy right compound alloy 


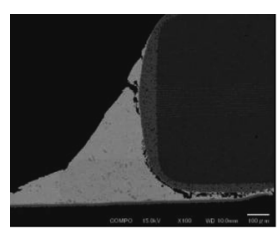

$30 \overline{0 \mu \mathrm{m}}$

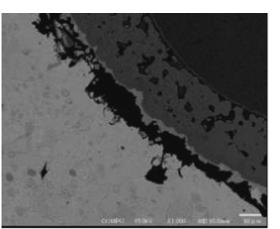

$30 \overline{\mu \mathrm{m}}$

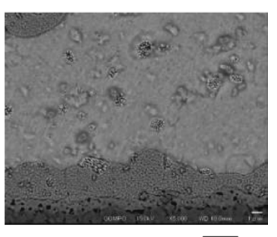

$3 \overline{\mu \mathrm{m}}$
Fig. 13 Breaking crack after cycle of $\mathrm{Sn}_{3} \mathrm{Ag}_{0.5} \mathrm{Cu}$

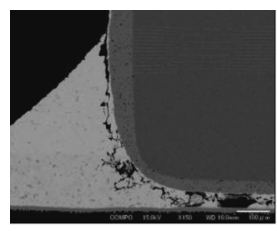

$\overline{200 \mu} \mathrm{m}$

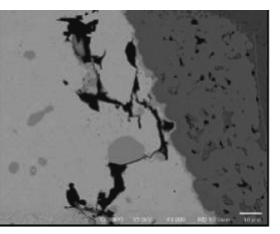

$\overline{30 \mu \mathrm{m}}$

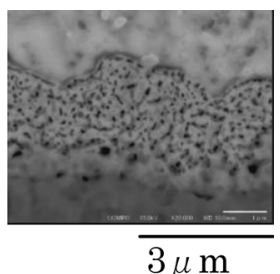

$3 \mu \mathrm{m}$
Fig. 14 Breaking crack after cycle of $\mathrm{Sn}_{1} \mathrm{Ag}_{0.5} \mathrm{Cu}$

るサイクル後の破断位置を示している。3Ag は部品電極界 面で破断し，1Agは，ほぼはんだでの破断である。この違 いははんだ自身の強度が異なること, 界面強度よりも $1 \mathrm{Ag}$ の粒界の強度が少し劣り, 温度サイクル負荷応力が作用す るとき，それに対しての抗力の大きさが影響していると考 える。また両者とも $\mathrm{Cu}_{3} \mathrm{~S} n$ 層でのボイドは生成しているが, ここでの破断クラック発生はなく, カーケンダルボイドが 接合部で最も弱いとは言えないことがわかった。

\section{4. 結 言}

（1）単一高融点はんだの代替として耐熱接合部を有する複 合型はんだ合金の信頼性試験や組織観察などを行っ た。ベースとして $\mathrm{Sn}_{3} \mathrm{Ag}_{0.5} \mathrm{Cu}, \mathrm{Sn}_{1} \mathrm{Ag}_{0.5} \mathrm{Cu}$ 合金，分散 材として Cu粉末，キャパシタ 3216，Cu padを主構成 とし, 恒温放置試験, 温度サイクル試験, 組織観察の 結果から IMCによる耐熱性，接合強度の推移など有益 性はあると考える。
（2）恒温放置試験結果は本材料において，強度の劣化はな く，単一合金の接合性と同じ特性を示すことが確認さ れた。また結果として初期と 1,000 時間後はほぼ同じ 強度で，このことは応力負荷がないことを示している。 また温度サイクル試験結果は複合材料の方が優性であ ることを示し，初期の $10 \%$ 程の劣性から試験後は $20 \%$ 以上の優性があった。

(3) 単一合金, 複合材の組織的特徵は $\mathrm{Cu}_{3} \mathrm{Sn}$ の成長, $\mathrm{Cu}$ 之 の界面および $\mathrm{Cu}_{3} \mathrm{Sn}$ 層におけるカーケンダルボイドの 発生があげられる。 $\mathrm{Cu}_{3} \mathrm{Sn}$ と $\mathrm{Cu}_{6} \mathrm{Sn}_{5}$ 間および $\mathrm{Cu}_{6} \mathrm{Sn}_{5}$ と はんだ間にはボイドやクラックの発生，あるいはそれ らの相内での発生もない。Ni padの時はCuがはんだ 中に多くとも接合界面は $\mathrm{Cu}_{6} \mathrm{Sn}_{5}$ であるため，同様にボ イドやクラックはない。

(4) バルクはんだのコストや強度などに影響を与える $\mathrm{Ag}$ の添加量は，長時間接合信頼性への影響はほぼないと 言える。サイクル熱応力時の破断位置の違い, 熱負荷 試験での $\mathrm{Ag}_{3} \mathrm{Sn}$ の変質に影響を受けているためと考え る。

(2008.3.25-受理)

\section{文献}

1) “高温鉛はんだ代替技術の現状と開発課題に関する調査 2005”，新エネルギー・産業技術総合開発機構

2）中野公介, 高岡英清, 辺 静春, 上島 稔：“耐熱 $\mathrm{Pb}$ ᄀ リーソルダーペーストの開発一粉末組成の制御による耐熱 化の検討”, 12th Symposium on “Microjoining and Assembly Technology in Electronics”, 溶接学会他，pp. 33-38， 2006

3) 大沼郁雄, 高久佳和, 曹 戦民, 貝沼亮介, 石田清仁 : “熱力学データベース ADAMISを利用した鉛フリーはんだ の合金設計と特性予測”，12th Symposium on “Microjoining and Assembly Technology in Electronics”, 溶接学会他, pp. 45-54, 2006 